\title{
A ship-based methodology for high precision atmospheric oxygen measurements and its application in the Southern Ocean region
}

\author{
By RONA L. THOMPSON ${ }^{1, *, \dagger}$, ANDREW C. MANNING ${ }^{2, \ddagger}$, \\ DAVID C. LOWE ${ }^{3}$ and DAVID C. WEATHERB U R N ${ }^{4},{ }^{1}$ Max Planck Institute for Biogeochemistry, Jena, \\ Germany; ${ }^{2}$ University of East Anglia, Norwich, England; ${ }^{3}$ National Institute for Water and Atmospheric Research, \\ Wellington, New Zealand; ${ }^{4}$ Victoria University of Wellington, New Zealand
}

(Manuscript received 22 December 2006; in final form 11 May 2007)

\begin{abstract}
AB STRACT
A method for achieving continuous high precision measurements of atmospheric $\mathrm{O}_{2}$ is presented based on a commercially available fuel-cell instrument, (Sable Systems, Oxzilla FC-II) with a precision of 7 per meg (approximately equivalent to $1.2 \mathrm{ppm}$ ) for a 6-min measurement. The Oxzilla was deployed on two voyages in the Western Pacific sector of the Southern Ocean, in February 2003 and in April 2004, making these the second set of continuous $\mathrm{O}_{2}$ measurements ever made from a ship. The results show significant temporal variation in $\mathrm{O}_{2}$, in the order of \pm 10 per meg over 6-hourly time intervals, and substantial spatial variation. Data from both voyages show an $\mathrm{O}_{2}$ maximum centred on $50^{\circ} \mathrm{S}$, which is most likely to be the result of biologically driven $\mathrm{O}_{2}$ outgassing in the region of subtropical convergence around New Zealand, and a decreasing $\mathrm{O}_{2}$ trend towards Antarctica. $\mathrm{O}_{2}$ from the ship-based measurements is elevated compared with measurements from the Scripps Institution of Oceanography flask-sampling network, and the $\mathrm{O}_{2}$ maximum is also not captured in the network observations. This preliminary study shows that ship-based continuous measurements are a valuable addition to current fixed site sampling programmes for the understanding of ocean-atmosphere $\mathrm{O}_{2}$ exchange processes.
\end{abstract}

\section{Introduction}

Atmospheric $\mathrm{O}_{2}$, when measured concurrently with $\mathrm{CO}_{2}$, is an excellent tracer for ocean-atmosphere and land-atmosphere exchanges of carbon, regionally as well as globally. For example, $\mathrm{O}_{2}$ measurements are used to partition carbon uptake between the land and ocean (e.g. Bender et al., 1996; Keeling et al., 1996; Keeling and Garcia, 2002; Manning and Keeling, 2006) and have been used to estimate ocean net biological production (Keeling and Shertz, 1992; Bender et al., 1996). The use of $\mathrm{O}_{2}$ and $\mathrm{CO}_{2}$ as a tracer is succinctly defined in the term, Atmospheric Potential Oxygen (APO), which is insensitive to terrestrial $\mathrm{O}_{2}$ and $\mathrm{CO}_{2}$ exchange, and hence largely reflects the changes in $\mathrm{O}_{2}$ and $\mathrm{CO}_{2}$ due to ocean fluxes (although fossil fuel burning also makes a small

*Corresponding author.

e-mail: rthompson@bgc-jena.mpg.de

${ }^{\dagger}$ Former address: The National Institute for Water and Atmospheric Research and Victoria University of Wellington, New Zealand.

${ }^{\ddagger}$ Former address: The Max Planck Institute for Biogeochemistry, Jena, Germany.

DOI: 10.1111/j.1600-0889.2007.00292.x contribution) (Stephens et al., 1998). APO can be expressed as:

$\mathrm{APO}=\mathrm{O}_{2}+\alpha_{\mathrm{B}} \times \mathrm{CO}_{2}$

where $\alpha_{\mathrm{B}}$ represents the average $-\mathrm{O}_{2}: \mathrm{CO}_{2}$ molar exchange for terrestrial ecosystems, and is quoted to be about 1.1 based on measurements by Severinghaus (1995) (APO is defined here with $\alpha_{\mathrm{B}}$ as a positive number according to convention, however, in the rest of paper we use $\mathrm{O}_{2}: \mathrm{CO}_{2}$ (instead of $-\mathrm{O}_{2}: \mathrm{CO}_{2}$ ) when discussing changes in $\mathrm{O}_{2}$ and $\mathrm{CO}_{2}$ because this ratio can be negative, for example for terrestrial ecosystem exchanges, or positive, for example for thermally driven air-sea gas exchanges). APO is particularly useful in determining spatial and temporal patterns of ocean $\mathrm{O}_{2}$ and $\mathrm{CO}_{2}$ transport, uptake and outgassing (e.g. Stephens et al., 1998; Gruber et al., 2001; Battle et al., 2006).

The Southern Ocean is particularly important for air-sea gas exchange of $\mathrm{O}_{2}$ and $\mathrm{CO}_{2}$ owing to the exposure of deep-water to the surface in this region, which results in ocean-atmosphere gradients in temperature and partial pressure, and hence large $\mathrm{O}_{2}$ and $\mathrm{CO}_{2}$ fluxes. Furthermore, this region has highly seasonal 
biological activity leading to additional seasonally varying biologically driven fluxes. Despite the importance of the Southern Ocean to global $\mathrm{O}_{2}$ and $\mathrm{CO}_{2}$ air-sea gas exchange, $\mathrm{O}_{2}$ data in this region are sparse. Current flask sampling networks only include seven stations in the Southern Hemisphere, of which only five are in the region of the Southern Ocean. Furthermore, flask samples, at the usual frequency of collection of once every 1-2 weeks, cannot capture short-term synoptic variability, and therefore are not well suited to studies of exchange processes. To better understand these processes, and to improve the spatial coverage of $\mathrm{O}_{2}$ measurements in the Southern Ocean region, ship-based measurements are needed.

The reason for the paucity of $\mathrm{O}_{2}$ data is in part due to the considerable challenge of developing methods to measure $\mathrm{O}_{2}$ to a level of precision sufficient to detect long-term background variations, that is, in the order of 2 ppm per year. Although the absolute changes in atmospheric $\mathrm{O}_{2}$ are comparable to those of $\mathrm{CO}_{2}$, they must be determined against a background concentration of about $20.9 \%$ (i.e. 209000 ppm), therefore, sensitive instruments and rigorous gas handling techniques are required to detect these relatively small changes. Currently employed methods include an interferometric technique (Keeling, 1988b), a technique based on mass spectrometry (Bender et al., 1994), a gas chromatographic technique (Tohjima, 2000), a technique using a paramagnetic analyser (Manning et al., 1999), an optical technique using vacuum ultraviolet absorption (VUV) (Stephens et al., 2003) and a fuel cell technique (Stephens et al., 2007).

To date, the only reported continuous ship-based atmospheric $\mathrm{O}_{2}$ measurements have been made using a VUV analyser (Stephens, 1999; Stephens et al., 2003). Although these are the only published continuous ship-based observations, flask samples have also been collected from ships for subsequent $\mathrm{O}_{2}$ analysis. The ship-based flask-sampling record was started in 1996 by Princeton University, U.S., using ships sailing in the Pacific Ocean with samples collected between $30^{\circ} \mathrm{N}$ and $30^{\circ} \mathrm{S}$, and in 2001 a second record was started by the National Institute for Environmental Studies, Japan, between Japan and Australia, and Japan and the United States, but neither record covers the region of the Southern Ocean south of $40^{\circ} \mathrm{S}$ (Tohjima et al., 2005; Battle et al., 2006).

In this paper, we present the design and development of a fuel cell method for continuous measurements of atmospheric $\mathrm{O}_{2}$ from onboard a ship. $\mathrm{O}_{2}$ is measured using a modified commercially available fuel cell instrument (Oxzilla FC-II), and $\mathrm{CO}_{2}$ is measured using a commercially available non-dispersive infrared analyser (LICOR 6252). The Oxzilla was first adapted for high precision atmospheric $\mathrm{O}_{2}$ measurements for a land-based site by the National Oceanic and Atmospheric Administration Global Monitoring Division (NOAA-GMD) in 2000 (Stephens et al., 2007), however, in this paper we focus on the description of the gas handling technique for a ship-based system, followed by calibration procedures and calculations in Section 2, and re- sults from our two voyages in the Pacific sector of the Southern Ocean are presented in Section 3.

\section{Measurement method}

\subsection{Operating principle of the $\mathrm{O}_{2}$ analyser}

The $\mathrm{O}_{2}$ analyser is a modification of a commercially available instrument from Sable Systems (model, Oxzilla FC-II). At the heart of this analyser are two weak-acid electrolyte $\mathrm{O}_{2}$ sensors, (Maxtec, MAX-250) consisting of a lead anode and a gold cathode. Air is allowed to permeate onto the cathode through a gas-porous membrane that is bonded to it; $\mathrm{O}_{2}$ is reduced at the cathode producing a current proportional to the partial pressure of $\mathrm{O}_{2}$ at the surface of the membrane, while lead is oxidized at the anode (the overall equation is shown in eq. 2).

$2 \mathrm{~Pb}+\mathrm{O}_{2}+4 \mathrm{H}^{+} \rightarrow 2 \mathrm{~Pb}^{2+}+2 \mathrm{H}_{2} \mathrm{O}$.

The presence of the acid-electrolyte has two advantages: first, the detection of $\mathrm{O}_{2}$ is unaffected by the presence of $\mathrm{CO}_{2}, \mathrm{CO}, \mathrm{SO}_{2}$ and $\mathrm{NO}_{x}$, which interfere with measurements in conventional cells, and second, the acid has a higher capacity to absorb $\mathrm{PbO}$ (a by-product of the redox reaction) with the result of increasing the cell lifetime.

Because the $\mathrm{O}_{2}$ measurement is based on partial pressure, it is affected by changes in the sample and barometric pressures. The signal output is linearly proportional to the resultant partial pressure of $\mathrm{O}_{2}$, and may therefore be corrected using a simple linear relationship (eq. 3) where $S_{m}$ is the measured output at pressure, $P$, and $S_{t}$ is the standardized output signal at 1013 mbar.

$S_{t}=S_{m} \times \frac{1013}{P}$.

The sensor responds to step changes in partial pressure by reaching $97 \%$ of the final value within a maximum of $25 \mathrm{~s}$.

Because the changes in $\mathrm{O}_{2}$ partial pressure to be detected are in the order of 1 in $10^{6}$, changes in the partial pressure of other gas species will significantly alter the $\mathrm{O}_{2}$ measurement, therefore, $\mathrm{O}_{2}$ concentrations are reported on a relative scale (Keeling and Shertz, 1992). This scale is calculated as the change in the ratio of $\mathrm{O}_{2}$ to $\mathrm{N}_{2}$ relative to a standard $\mathrm{O}_{2}$ to $\mathrm{N}_{2}$ ratio (see eq. 4) and changes in this ratio, $\delta\left(\mathrm{O}_{2} / \mathrm{N}_{2}\right)$, are expressed in 'per meg' units (Keeling and Shertz, 1992).

$\delta\left(\mathrm{O}_{2} / \mathrm{N}_{2}\right)=\frac{\left(\mathrm{O}_{2} / \mathrm{N}_{2}\right)_{\mathrm{sam}}-\left(\mathrm{O}_{2} / \mathrm{N}_{2}\right)_{\mathrm{ref}}}{\left(\mathrm{O}_{2} / \mathrm{N}_{2}\right)_{\mathrm{ref}}} \times 10^{6}$.

\subsection{Description of the gas handling system}

To achieve high accuracy in $\mathrm{O}_{2}$ measurements, a number of important gas handling effects needed to be taken into account, particularly, molecular fractionation and absorption. Changes in the $\mathrm{O}_{2}$ mole fraction in air can occur through diffusive separation of $\mathrm{O}_{2}$ relative to $\mathrm{N}_{2}$ induced by temperature, pressure, or water 
vapour gradients, and through the absorption of $\mathrm{O}_{2}$ and/or $\mathrm{N}_{2}$ onto surfaces or by their diffusion across permeable solids. All of these effects can interfere with the measurement of biogeochemical $\mathrm{O}_{2}$ signals.

Diffusive separation effects in the context of atmospheric $\mathrm{O}_{2}$ measurements have been previously observed (e.g. Keeling et al., 1998, 2007; Manning, 2001; Langenfelds et al., 2005). In environments with varying temperature, pressure or humidity, $\mathrm{O}_{2}$ has been observed to accumulate preferentially in regions with lower temperature, higher pressure, or higher absolute humidity (e.g. Chapman and Cowling, 1970; Keeling et al., 1998). Another potential fractionation mechanism, known as Knudsen diffusion, is flow through any small orifice, such as a leak, with a diameter less than that of the mean-free path between molecular collisions (Dushman, 1962). The molecular flow is proportional to the partial pressure drop through the orifice and the molecular velocity, which varies inversely with the square root of the molecular weight (Dushman, 1962). The ratio of $\mathrm{O}_{2}$ to $\mathrm{N}_{2}$ escaping through an orifice with a large pressure drop is therefore $(28 / 32)^{1 / 2}=0.935$ times smaller than the ratio upstream of the orifice. For example, a leak that leads to a loss of $0.1 \%$ of the sample could potentially enrich the sample by 65 per meg. The mechanisms of diffusive separation are also manifest at ' $\mathrm{T}$ '-junctions, where an incoming flow divides into two branches, and is most likely to occur when a temperature or pressure gradient exists across the branches (Manning, 2001).
To avoid fractionation effects, the gas handling system was designed to be free of ' $\mathrm{T}$ '-junctions, and to minimize problems of absorption and permeation of gases, plastic was avoided on all surfaces in contact with the air sample. For this reason, the Oxzilla and LICOR were also modified so that all plastic tubing and fittings were replaced with $1 / 8$-inch stainless steel tubing and fittings (we also removed the aluminium coil of tubing inside the Oxzilla, which was used for heat transfer, as it was subsequently redundant). Leaks were also originally a problem with the Oxzilla, particularly where the fuel cells were mounted on an aluminium block that connected them to the airlines. This was solved by fine-polishing the aluminium surface in contact with the cells and by using Teflon grease to improve the seal of the cells' o-ring to this surface. By making these simple modifications to the Oxzilla we were able to improve on the stated precision (of approximately $10 \mathrm{ppm}$ ) to achieve a precision of $1.2 \mathrm{ppm}$ (equivalent to approximately 7 per meg) over a 6-min averaging interval.

The gas handling system used is shown in Fig. 1. The presence of two cells in the Oxzilla means that the analyser can be used differentially, that is, $\mathrm{O}_{2}$ can be measured as the difference in partial pressure as measured by each cell. Sample air was pumped continuously from the air inlet (for the ship-board measurements, this was mounted at the crow's nest) and through the gas handling system at a flow rate of approximately $100 \mathrm{~mL} \mathrm{~min}^{-1}$. At the air inlet, $7-\mu \mathrm{m}$ filters were used to filter out large aerosol particles.

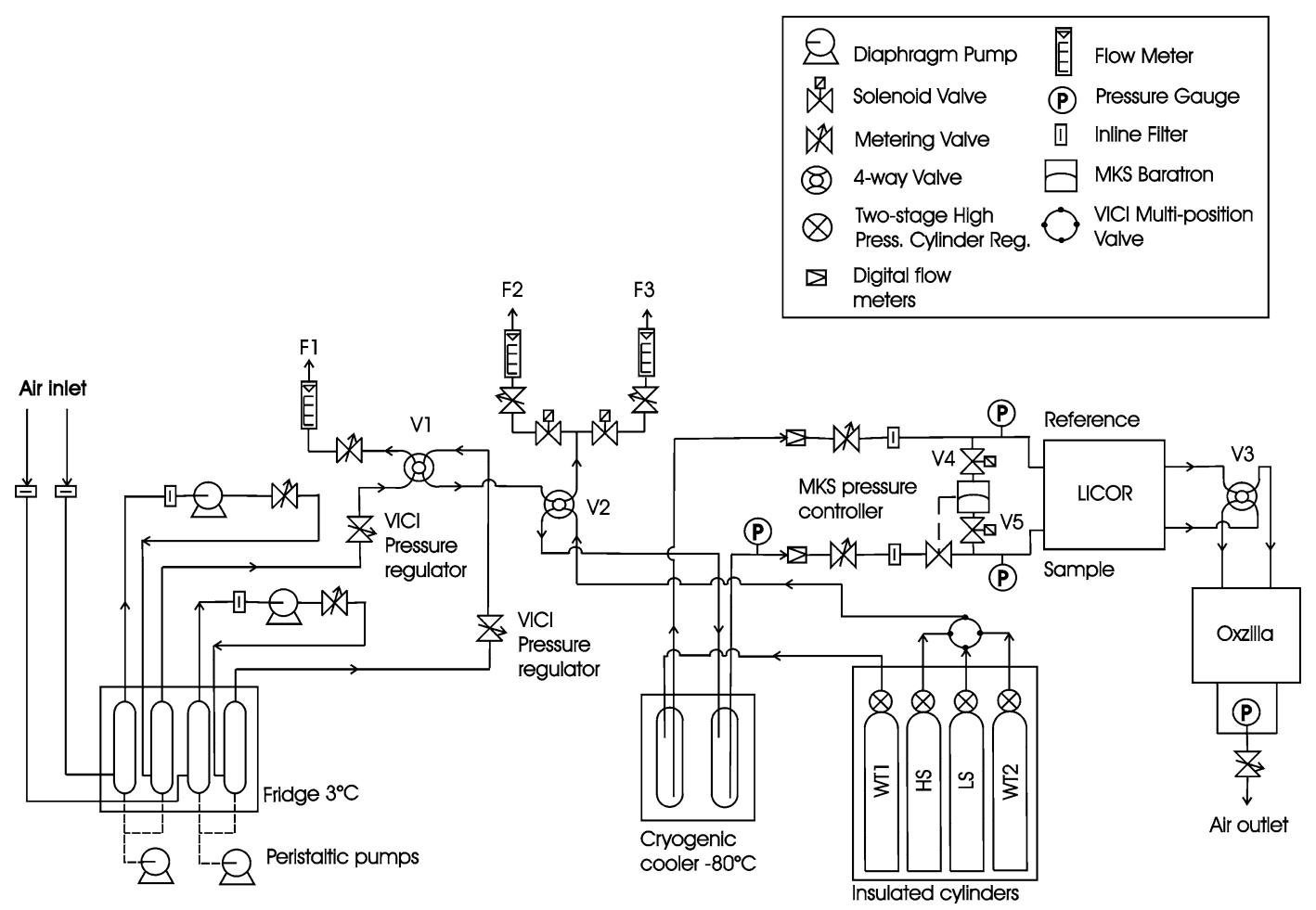

Fig. 1. Schematic of the gas handling system with the Sable Systems Inc. Oxzilla FC-II and LICOR 6252 analysers. 
Two air-inlet lines (of Dekabon tubing, $1 / 2$-inch diameter) were available for use, one being only used as a back up in case the other became blocked or contaminated.

The gas handling, that is, drying the air, controlling the pressure and flow-rate, and the analyses, were made in an airconditioned laboratory on-board the ship. Here, the air was first dried through a glass trap $\left(250 \mathrm{~cm}^{3}\right)$ filled with glass beads (Pyrex, $2 \mathrm{~mm}$ ), resulting in a remaining air volume of approximately $120 \mathrm{~cm}^{3}$, and which was cooled to $3{ }^{\circ} \mathrm{C}$ using a small refrigerator. We chose to dry the air before it passed through the pumps to avoid moisture accumulating in the pumps and therefore prolonging the time before requiring maintenance. Diaphragm pumps (KNF Neuberger, model N05), which have been shown not to produce artefacts in analysis for either $\mathrm{O}_{2}$ or $\mathrm{CO}_{2}$ (Manning, 2001), were used to draw air through the airlines. The air was then further dried through a second glass trap (also at $3{ }^{\circ} \mathrm{C}$ ) and since the air is now at higher pressure, more water will condense. Condensed water was removed from the traps using peristaltic pumps at a flowrate of approximately $1 \mathrm{~mL} \mathrm{~min}^{-1}$ that provided a constant air lock between the trap and outside air with minimal loss of the sample air.

After the second trap, a pressure regulator (VICI, model PR50) was used in each airline for coarse pressure control. After this point, one airline was selected for analysis with a four-way valve (V1, Numatech, TM-series), and the other was vented to the room (point F1). A second four-way valve (V2) was then used to select between sample air and calibration gas, and when sample air was not being sampled, it was also vented to the room (point F3). By maintaining a continuous flow of air at the same flow rate, we could avoid long re-equilibration times required for steady-state to be re-established inside the airlines coming from the inlet on the crow's nest. Before a calibration gas was passed through the analysers, it was purged through point F2 to flush the line and the cylinder regulator. Air and calibration gas were further dried using a stainless steel trap $\left(150 \mathrm{~cm}^{3}\right)$ filled with glass beads that was cooled to $-80{ }^{\circ} \mathrm{C}$ with a cryogenic cooler (FTS Kinetics, VT490D) to achieve a water content of approximately $2 \mathrm{ppm}$. Filling the traps with beads served the purpose of reducing the volume of air inside the trap (the remaining volume is approximately $70 \mathrm{~cm}^{3}$ ). Normally a gradient in the $\mathrm{O}_{2} / \mathrm{N}_{2}$ ratio exists from inside the trap (at $-80{ }^{\circ} \mathrm{C}$ ) to the exit (at approximately $20{ }^{\circ} \mathrm{C}$ ) owing to thermal diffusion, but under steady flow and pressure conditions the $\mathrm{O}_{2} / \mathrm{N}_{2}$ ratio of air passing through the trap is not affected (Severinghaus et al., 1996; Manning, 2001). However, a pressure pulse caused, for example, by switching between air and calibration gas disrupts this steady-state sending a pulse of high $\mathrm{O}_{2} / \mathrm{N}_{2}$ air to the analyser. By reducing the air volume inside the trap, the time for re-establishing steady-state is also reduced.

Because both analysers are used in differential mode, that is measuring relative to a reference gas (referred to as Working Tank, WT1), it was critical that the pressure difference between sample and reference lines was kept constant at all times. To achieve this, the WT1 pressure was set using a pressure regulator (Scott Specialty Gases, model 51-14C) and the pressure in the sample line was adjusted to match that of WT1 using an inline solenoid valve (MKS, model 248A). The differential pressure was measured using a transducer (MKS, Baratron 223BD) and was fed into a control unit (MKS, 250B) and used to adjust the solenoid valve in the sample line (see Fig. 1). With this set-up, the differential pressure could be controlled so that the changes were less than 0.01 mbar (equivalent to $0.001 \%$ ) over a 60-min interval. The solenoid valves (V4 and V5) on either side of the transducer were used to protect it from accidental over pressure and were activated automatically if the differential pressure exceeded 20 mbar.

We chose to place the Oxzilla and LICOR analysers in series to avoid the problems of fractionation associated with ' $\mathrm{T}$ 'junctions. Immediately upstream of the Oxzilla, we used two three-way valves (V3, Numatech model, TM-101-V-12C1) in combination to make one four-way valve to switch between WT1 and sample air, so in effect, switching which Oxzilla cell was acting as the reference cell and which was acting as the sample cell, following the method of Stephens et al. (2007). This switching was made continuously every $120 \mathrm{~s}$ during all measurements to eliminate any bias arising from small differences in cell sensitivity (see Section 2.3 for more details on how this was accounted for). The switching interval was determined by the time needed for the measurement to restabilize after each switch and was partly dependent on the time needed for a stable pressure to be reached. For future measurements, the response time might be improved by trying to equalize the pressure restriction on both sides after the switching valve, V3.

The gas handling system and analysers were interfaced using a desktop computer. We used hardware from National Instruments to sample both the LICOR and Oxzilla outputs at a frequency of $10 \mathrm{~Hz}$ using a data acquisition board, which was also used as an analogue to digital converter (NI model, PCI-6033E) in conjunction with a terminal board (NI model, SCB100). To interface the hardware we wrote a customized programme for controlling the gas handling system and for recording and processing data using LabVIEW, a graphical based programming language. With the described set-up, the system could be run automatically and only required attendance about once per week to defrost the stainless steel traps, which block with ice, or in case of instrumental malfunction.

There were a number of additional considerations for the installation onboard a ship; these included the ship's motion and vibration. The equipment was installed in racks that were tightly secured to the deck, and although pitching and rolling did not affect the instrumentation, vibration in the deck increased the analyser noise. This problem was minimized by insulating the racks from the deck using rubber mats (of approximately $20 \mathrm{~mm}$ thickness). 


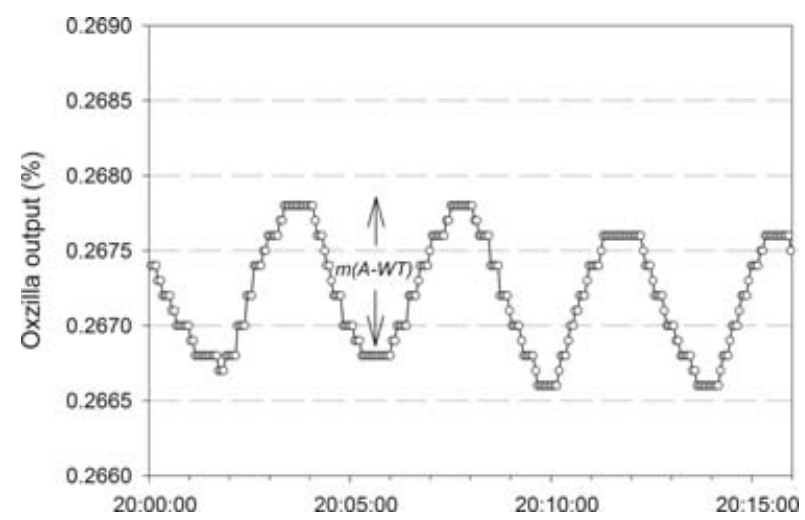

Fig. 2. An example of the Oxzilla output showing the difference in delta while switching the cell acting as the reference cell and the cell acting as the sample cell at a frequency of $2 \mathrm{~min}$. The data shown are the Oxzilla output (using the Oxzilla's own internal averaging) at a frequency of approximately 6-s (Oxzilla output has resolution limited to $0.0001 \%)$. These data were collected onboard Tangaroa.

\section{$2.3 \mathrm{O}_{2}$ calculations and calibration}

To calculate the $\mathrm{O}_{2}$ concentration, we needed to correct for the baseline drifts of the two cells. This was achieved by measuring the change in the differential signal as the cell acting as the reference cell and the cell acting as the sample cell were switched. This change in the differential signal is referred to as $\Delta(\Delta)$, and is proportional to the difference between the sample and reference concentrations (in units of $\mathrm{O}_{2} \%$ ):

$\Delta(\Delta)=\left(A_{s}-W T_{r}\right)-\left(W T_{s}-A_{r}\right)$,

$\Delta(\Delta)=m(A-W T)$,

where $(A-W T)$ is the difference between sample air and Working Tank 1 , and the subscripts denote sample cell $(s)$ or reference cell ( $r$ ) (see Fig. 2). For the values of $A$ and $W T$, we use the average of the last $20 \mathrm{~s}$ of the 120 -s measurement and discard the first $100 \mathrm{~s}$ after switching while a stable value is still being reached. If the sensitivity of both cells were exactly the same then $m$ would equal 2 . The actual value of $m$ is determined by a daily calibration and in reality has a value close to 2 . Figure 2 shows an example of the Oxzilla signal with this switching visible as a wave with an amplitude equivalent to approximately twice the difference in concentration between the reference and sample gases.

Both the LICOR and Oxzilla were calibrated initially using a suite of 4 and 3 calibration gases, respectively. From this calibration, the LICOR and the Oxzilla were found to both have a linear response $\left(r^{2}=0.9998\right.$ and 0.998 , respectively) within the range of 340-390 ppm for $\mathrm{CO}_{2}$, and -400 to -200 per meg for $\mathrm{O}_{2}$, which covered the range of ambient variations expected. During the ship voyages, the calibrations were made using only 2 gases owing to a shortage of space for cylinders on-board. The gases used were a High Span (HS) with high $\mathrm{O}_{2}$ and low $\mathrm{CO}_{2}$ concentrations, and a Low Span (LS) with low $\mathrm{O}_{2}$ and high $\mathrm{CO}_{2}$ concentrations, and were calibrated for $\mathrm{O}_{2}$ against standards at NIWA [which were calibrated originally against Scripps Institution of Oceanography (SIO) standards], and for $\mathrm{CO}_{2}$ against NOAA-GMD standards. Because thermal fractionation of $\mathrm{O}_{2}$ to $\mathrm{N}_{2}$ can also be a problem within cylinders (Keeling et al., 2007), the calibration gases and WT1 were wrapped in industrial thermal insulation sheets to prevent temperature gradients across the cylinders. In addition, the cylinders were kept horizontally throughout the voyages to further reduce the effects of thermal fractionation (as the vertical temperature gradient from the floor to 1-2 m height is usually greater than the horizontal gradient). Furthermore, having the cylinders horizontal helped to reduce the potential for gravitational separation of $\mathrm{O}_{2}$ to $\mathrm{N}_{2}$, an effect that increases with increasing cylinder pressure (Burton, 1967).

The $\mathrm{O}_{2} / \mathrm{N}_{2}$ ratio, $\delta\left(\mathrm{O}_{2} / \mathrm{N}_{2}\right)$, of the sample gas was calculated from $\Delta(\Delta)$ as follows:

$A-W T=\frac{\Delta(\Delta)}{m}$

$A(\mathrm{ppm})=\frac{\Delta(\Delta)}{m} \times 10^{4}+W T(\mathrm{ppm})$

$\delta\left(\mathrm{O}_{2} / \mathrm{N}_{2}\right)($ per meg $)=\frac{A(\mathrm{ppm})+\left(\left[\mathrm{CO}_{2}\right]-363.29\right) \times \mathrm{XO}_{2}}{\left(1-\mathrm{XO}_{2}\right) \mathrm{XO}_{2}}$,

where (7) is simply a re-arrangement of (6), and in (8) $\Delta(\Delta)$ is converted from $\%$ to ppm by multiplying by $10^{4}$. In (9), $\mathrm{XO}_{2}$ is the approximate mole fraction of $\mathrm{O}_{2}$ in air $\left(\mathrm{XO}_{2}=0.20946\right.$, Machta and Hughes, 1970) and $\left(\left[\mathrm{CO}_{2}\right]-363.29\right)$ is the $\mathrm{CO}_{2}$ concentration in the sample gas minus an arbitrary reference $\mathrm{CO}_{2}$ concentration (ppm) used to correct for the relative amount of $\mathrm{CO}_{2}$ dilution (for a more thorough explanation of eq. 9 see Keeling et al., 1998). Between calibrations, which were made daily, a second reference gas (WT2) was measured approximately every $2 \mathrm{~h}$ to correct for residual drift in the analyser baselines. An example of a calibration for $\mathrm{O}_{2}$ and $\mathrm{CO}_{2}$ is shown in Fig. 3. All calibration gases were measured for a 20-min period with typical $1 \sigma$ standard deviations of \pm 7 per meg $\mathrm{O}_{2}$ and $\pm 0.1 \mathrm{ppm} \mathrm{CO}_{2}$ based on the average of the last $6 \mathrm{~min}$ of 20 -min measurements (that is, the last 3 out of 10 switching cycles). We estimated the longer-term precision in the measurements from the standard deviation of the WT2 over the course of a voyage, that is, over approximately 2 weeks, for $\mathrm{O}_{2}$ this was \pm 5 per meg and for $\mathrm{CO}_{2}, \pm 0.1 \mathrm{ppm}$.

\section{Results and discussion}

The data presented here were collected on two voyages of the National Institute for Water and Atmospheric Research (NIWA) ship, Tangaroa. On each of these voyages, the air inlets were installed at the crow's nest, $65 \mathrm{~m}$ in front of the ship's exhaust and $25 \mathrm{~m}$ above sea level. Although the air intakes were located fore of the exhaust funnel, it was still necessary to filter the data 


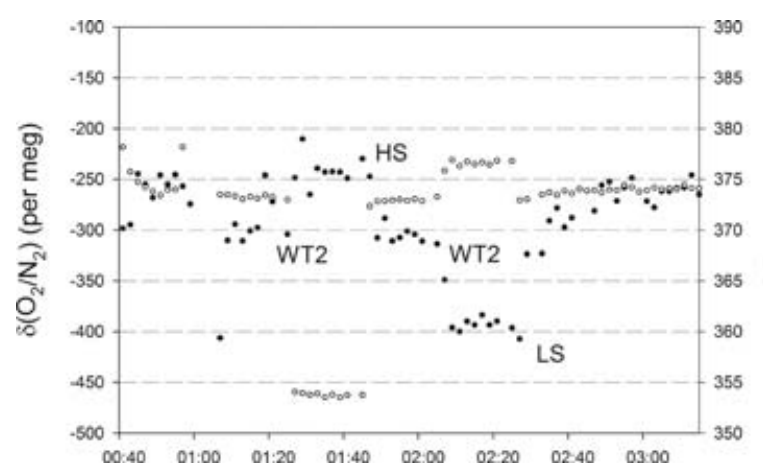

Fig. 3. An example of a daily calibration run while onboard Tangaroa, showing $\delta\left(\mathrm{O}_{2} / \mathrm{N}_{2}\right)$ (solid circles) and $\mathrm{CO}_{2}$ (hollow circles) concentrations. Each of HS, LS and WT2 were analysed for $20 \mathrm{~min}$ each. Data are plotted at 2-min frequency representing the $\Delta(\Delta)$ value found for each switch in the cycle. The final value for each gas was taken from the average of the last 6 min of the sample. Air concentrations are shown before the first WT2 and after LS. These data were collected onboard Tangaroa.

occasionally for contamination from the ship's exhaust when the wind speed, relative to the ship, was very low or when the prevailing wind came from across the stern. Occasions of exhaust contamination were identified by large fluctuations in $\mathrm{O}_{2}$ and $\mathrm{CO}_{2}$ that were much larger than any possible changes in background concentrations and by the strong negative $\mathrm{O}_{2}$ to $\mathrm{CO}_{2}$ correlation with a molar ratio of approximately $\left.-1.4\left(\mathrm{~mol} \mathrm{~mol}^{-1}\right)\right]$, which is indicative of liquid fossil fuel combustion (Keeling, 1988a; see also Section 3.2).

\subsection{February 2003 voyage}

We first deployed the Oxzilla and LICOR, with the gas handling system, onboard Tangaroa, on a round trip from Wellington, New Zealand $\left(41.4^{\circ} \mathrm{S}, 174.9^{\circ} \mathrm{E}\right)$ to the Adelie Coast, Antarctica $\left(64.5^{\circ} \mathrm{S}, 140^{\circ} \mathrm{E}\right.$ ) (see Fig. 4). The Tangaroa departed on 18 February 2003 and made a 6-d transect across the Southern Ocean arriving at the Adelie Coast on 24 February. Unfortunately no data could be collected on the return leg due to an equipment failure.

$\delta\left(\mathrm{O}_{2} / \mathrm{N}_{2}\right)$ and $\mathrm{CO}_{2}$ data collected on the southbound leg of the voyage are shown in Fig. 5 as hourly averages plotted against time with the approximate latitude of the ship shown on the upper $x$-axis. Hourly averaged data are shown as the variability on shorter timescales is difficult to interpret meaningfully, with the standard deviation of $\delta\left(\mathrm{O}_{2} / \mathrm{N}_{2}\right)$ for a 1-h interval typically having values of around 10 per meg. The gap in the dataset from 19 to 20 February is where data were filtered out because of suspected exhaust contamination. On 18 February, as Tangaroa passed the length of the South Island of New Zealand, $\delta\left(\mathrm{O}_{2} / \mathrm{N}_{2}\right)$ increased coinciding with a relatively small increase in $\mathrm{CO}_{2}$ concentration. Once south of New Zealand, $\delta\left(\mathrm{O}_{2} / \mathrm{N}_{2}\right)$ increased a further 30 per meg from $47^{\circ} \mathrm{S}$ to $49^{\circ} \mathrm{S}$ corresponding with a

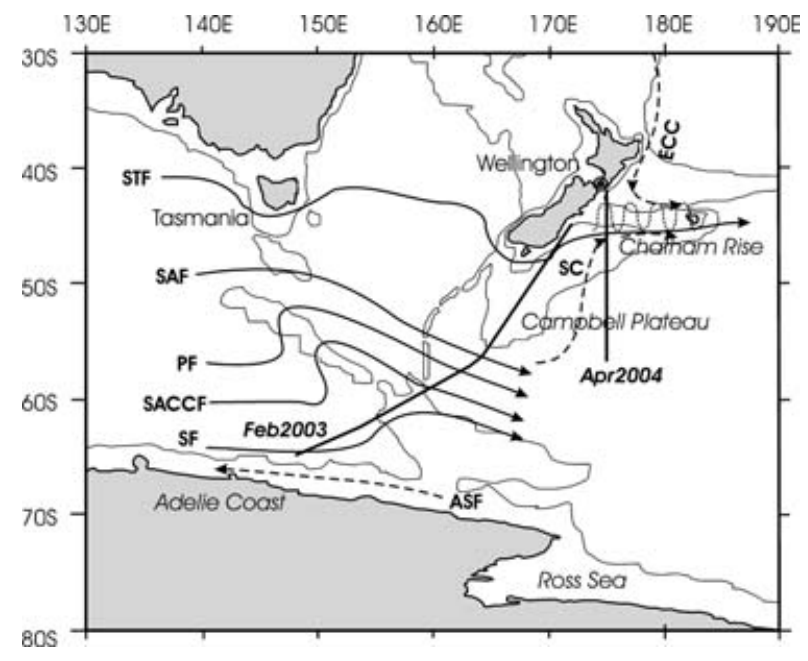

Fig. 4. Map of the Western Pacific sector of the Southern Ocean showing the currents associated with the Antarctic Circumpolar Current (ACC): Sub-Antarctic Front (SAF), Polar Front (PF), Southern ACC Front (SACCF), Southern Front (SF), and the Antarctic Slope Front (ASF). Also shown are: the Sub-Tropical Front (STF), East Cape Current (ECC) and the Southland Current (SC). Other regions of interest are the Chatham Rise, where the SC mixes with the ECC (mixing shown as wavy dotted line), and the Campbell Plateau. The ship transects are shown by the bold solid lines.

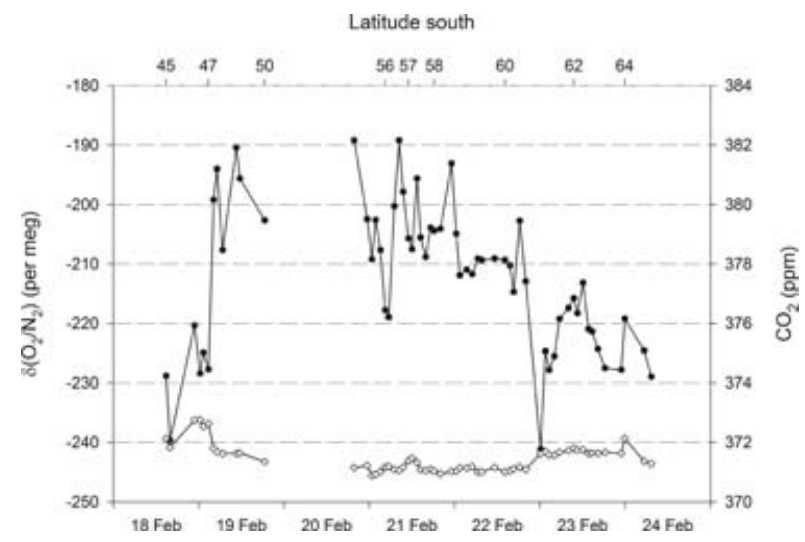

Fig. 5. February 2003: hourly mean values of $\delta\left(\mathrm{O}_{2} / \mathrm{NO}_{2}\right)$ (black circles) and $\mathrm{CO}_{2}$ (white diamonds) plotted versus time. The approximate latitudinal position of Tangaroa is shown on the upper $x$-axis. The $\delta\left(\mathrm{O}_{2} / \mathrm{N}_{2}\right)$ and $\mathrm{CO}_{2}$ axes have been scaled so that the full scale range shown is equivalent on a molar basis.

decrease in $\mathrm{CO}_{2}$ of $1.3 \mathrm{ppm}$. After the data record was resumed at $54^{\circ} \mathrm{S}$, high $\delta\left(\mathrm{O}_{2} / \mathrm{N}_{2}\right)$ and low $\mathrm{CO}_{2}$ were still observed, but with variability on an hourly timescale. South of $57^{\circ} \mathrm{S}, \delta\left(\mathrm{O}_{2} / \mathrm{N}_{2}\right)$ gradually declined while $\mathrm{CO}_{2}$ increased. During this trend, a sudden dip in $\delta\left(\mathrm{O}_{2} / \mathrm{N}_{2}\right)$ at $61^{\circ} \mathrm{S}$ of 35 per meg was observed with a concurrent step increase in $\mathrm{CO}_{2}$ of $0.8 \mathrm{ppm}$.

To aid the interpretation of these data, we used the meteorological record collected onboard Tangaroa. In Fig. 6, we show $\delta\left(\mathrm{O}_{2} / \mathrm{N}_{2}\right)$ together with wind speed and direction, and air 


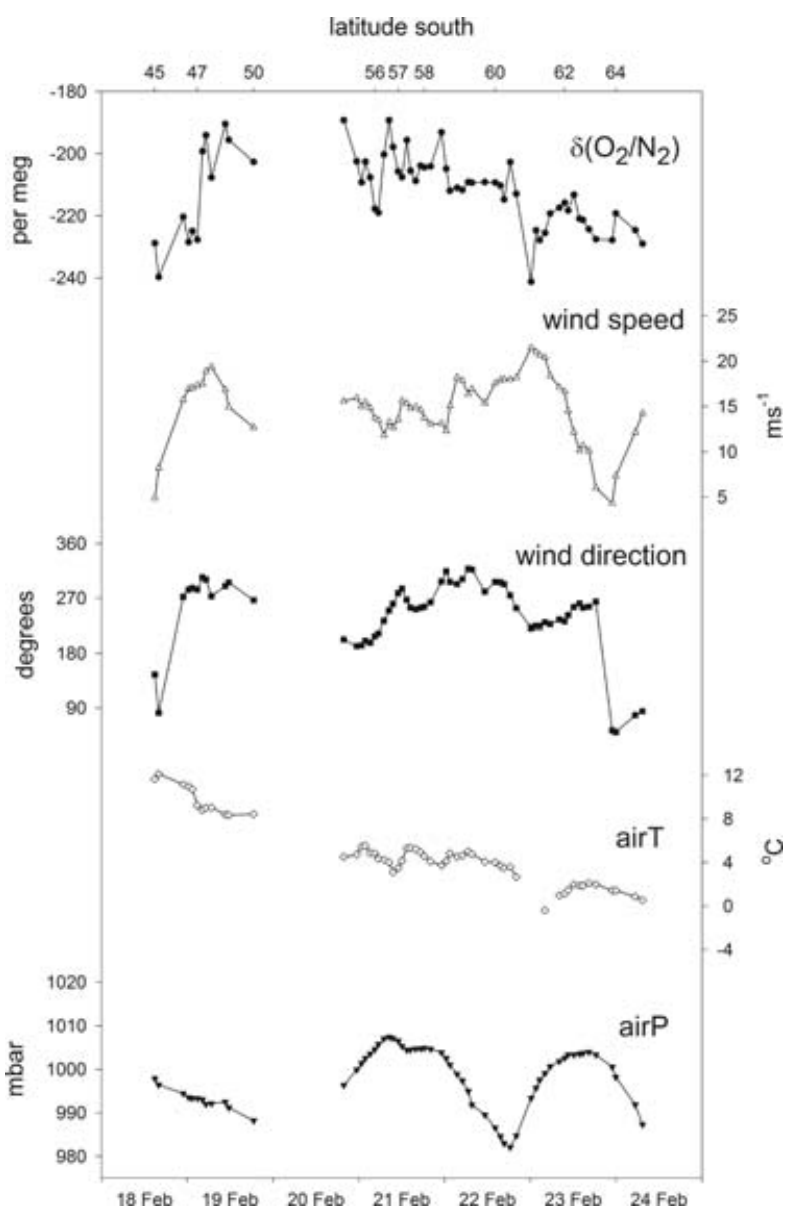

Fig. 6. February 2003: hourly mean $\delta\left(\mathrm{O}_{2} / \mathrm{N}_{2}\right)$ and meteorological data (collected onboard Tangaroa) plotted versus time with the approximate latitude indicated on the upper $x$-axis.

temperature and pressure plotted against time. At the beginning of the voyage, north of $46^{\circ} \mathrm{S}$, low wind speeds and westerly wind directions were observed (although at the start of the voyage the wind appears to be from the southeast to east in Fig. 6, this is most likely a very local effect while back trajectories plotted with the HySplit4 (Draxler and Hess, 1998) show the origin of the air to be from the west at this time $)$. The low $\delta\left(\mathrm{O}_{2} / \mathrm{N}_{2}\right)$ signal at this time is therefore likely to reflect the $\mathrm{O}_{2}$ concentration in local air masses, and thus to some extent the influence of local ocean-atmosphere $\mathrm{O}_{2}$ exchange. South of $46^{\circ} \mathrm{S}$, the wind speed increased coinciding with an observed increase in $\delta\left(\mathrm{O}_{2} / \mathrm{N}_{2}\right)$ and most likely reflected a change in sampled air mass, from coastal to over the open ocean. Over the Southern Ocean there is very little terrestrial influence on air masses, therefore, the higher $\delta\left(\mathrm{O}_{2} / \mathrm{N}_{2}\right)$ and lower $\mathrm{CO}_{2}$ reflect predominantly ocean-atmosphere exchange. From $48^{\circ} \mathrm{S}$ to $62^{\circ} \mathrm{S}$, westerly to southerly winds prevailed and the wind speed was more than $10 \mathrm{~ms}^{-1}$. During this time, $\delta\left(\mathrm{O}_{2} / \mathrm{N}_{2}\right)$ was higher than that observed north of $46^{\circ} \mathrm{S}$ but varied by up to \pm 10 per meg over 6-hourly intervals. In contrast, $\mathrm{CO}_{2}$ was relatively stable, changing by less than \pm 0.25 ppm over the same time intervals. This is not a surprising result as oceanatmosphere $\mathrm{CO}_{2}$ exchange occurs much slower and equilibration takes in the order of $1 \mathrm{yr}$ compared with 1 week for $\mathrm{O}_{2}$ (Broecker and Peng, 1974).

The gradually decreasing $\delta\left(\mathrm{O}_{2} / \mathrm{N}_{2}\right)$ trend observed from approximately south of $57^{\circ} \mathrm{S}$ occurred while strong westerly winds still predominated. The $\delta\left(\mathrm{O}_{2} / \mathrm{N}_{2}\right)$ trend could be related to the influence of the Antarctic Circumpolar Current (ACC), which has its northern boundary at approximately $59^{\circ} \mathrm{S}$ at this longitude (Rintoul et al., 2001). The region of the ACC characteristically has low biological productivity, and deep mixing that brings $\mathrm{O}_{2}$-depleted and $\mathrm{CO}_{2}$-rich water to the surface resulting in a net influx of $\mathrm{O}_{2}$ and efflux of $\mathrm{CO}_{2}$ (Volk and Hoffert, 1985; Sarmiento et al., 1995). Deep mixing and subsequent $\mathrm{O}_{2}$ influx is likely to be the cause of the observed decrease in atmospheric $\mathrm{O}_{2}$ over the ACC region. At $61^{\circ} \mathrm{S}$, we observed a relatively large, sudden decrease in $\delta\left(\mathrm{O}_{2} / \mathrm{N}_{2}\right)$ and an increase in $\mathrm{CO}_{2}$ that coincided with winds speeds of over $20 \mathrm{~ms}^{-1}$ and a change from a low to a high pressure system. We hypothesize that the combination of an atmospheric depression followed by very high wind speeds may be responsible for an ocean upwelling event and the subsequent uptake of $\mathrm{O}_{2}$ and outgassing of $\mathrm{CO}_{2}$ seen in our atmospheric data. South of the Southern Front (SF) and south of the ACC, the wind direction changed to easterly and the wind speed temporarily dropped to $5 \mathrm{~ms}^{-1}$. The small increase in $\delta\left(\mathrm{O}_{2} / \mathrm{N}_{2}\right)$ and $\mathrm{CO}_{2}$ observed appears to be the result of a change in sampled air mass, from that over the ACC, to air coming off the Antarctic continent.

\subsection{April 2004 voyage}

Data from our second cruise were collected on a roundtrip voyage of Tangaroa, departing Wellington, New Zealand on 17 April 2004 to an oceanographic mooring site at $56.7^{\circ} \mathrm{S}, 174.7^{\circ} \mathrm{E}$ and then back to Wellington, arriving on 29 April 2004 (see Fig. 4). $\delta\left(\mathrm{O}_{2} / \mathrm{N}_{2}\right)$ and $\mathrm{CO}_{2}$ from the south- and north-bound legs are shown together in Fig. 7 as hourly averages plotted against time with the approximate latitude of the ship shown on the upper $x$-axis. The southbound leg ended at the mooring site on 21 April, after which the ship circled within 1-2 degrees of the site for 3 $\mathrm{d}$ before beginning the northbound leg on 24 April.

From 18 to 19 April, as the ship passed the length of the South Island, New Zealand, $\delta\left(\mathrm{O}_{2} / \mathrm{N}_{2}\right)$ increased by 13 per meg from $44^{\circ} \mathrm{S}$ to $47^{\circ} \mathrm{S}$, during which time $\mathrm{CO}_{2}$ decreased by $5.6 \mathrm{ppm}$. South of $47^{\circ} \mathrm{S}, \delta\left(\mathrm{O}_{2} / \mathrm{N}_{2}\right)$ increased a further 12 per meg with a concurrent decrease in $\mathrm{CO}_{2}$ of $1.1 \mathrm{ppm}$. Once in the open ocean, south of $49^{\circ} \mathrm{S}, \delta\left(\mathrm{O}_{2} / \mathrm{N}_{2}\right)$ and $\mathrm{CO}_{2}$ became more stable but variations of approximately \pm 5 per meg and $\pm 0.1 \mathrm{ppm}$ were still observed throughout the southbound leg and for most of the time that the ship was circling the mooring site. During the northbound leg, $\delta\left(\mathrm{O}_{2} / \mathrm{N}_{2}\right)$ increased by a total of 48 per meg, reaching a maximum at $50^{\circ} \mathrm{S}$. This was not a steady increase but 


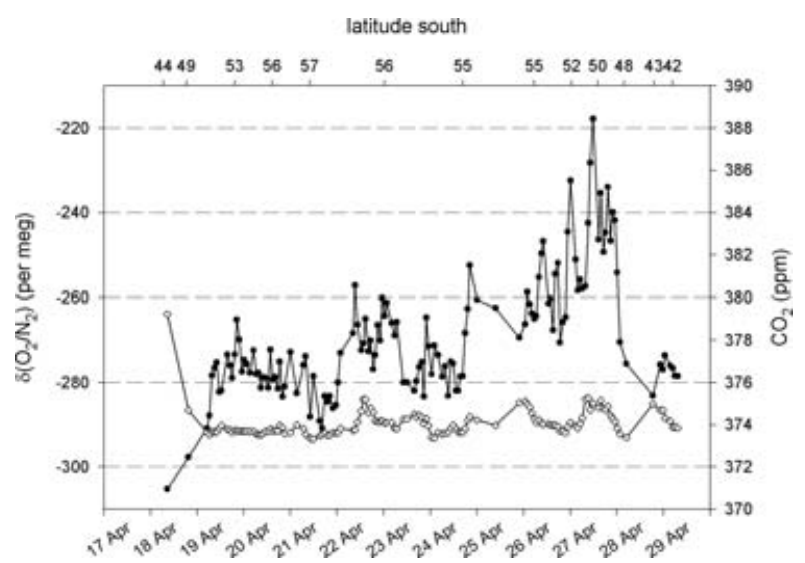

Fig. 7. April 2004: hourly mean values of $\delta\left(\mathrm{O}_{2} / \mathrm{N}_{2}\right)$ (black circles) and $\mathrm{CO}_{2}$ (white diamonds) plotted versus time. The approximate latitude of Tangaroa is shown on the upper $x$-axis. The $\delta\left(\mathrm{O}_{2} / \mathrm{N}_{2}\right)$ and $\mathrm{CO}_{2}$ axes have been scaled so that the full scale range shown is equivalent on a molar basis.

a series of positive excursions in $\delta\left(\mathrm{O}_{2} / \mathrm{N}_{2}\right)$ (see Fig. 7). Interestingly, the last excursion between $52^{\circ} \mathrm{S}$ and $48^{\circ} \mathrm{S}$ occurred with a concurrent increase in $\mathrm{CO}_{2}$. North of $47^{\circ} \mathrm{S}, \delta\left(\mathrm{O}_{2} / \mathrm{N}_{2}\right)$ decreased rapidly again and was negatively correlated with an increase in $\mathrm{CO}_{2}$.

As with the February 2003 data, we have used the meteorological record from Tangaroa to aid the interpretation of the results (Fig. 8). At the start of the voyage, south to easterly winds were experienced but once the ship reached the open ocean south of $49^{\circ} \mathrm{S}$, the wind direction changed to predominantly westerly. This change coincided with an increase in $\delta\left(\mathrm{O}_{2} / \mathrm{N}_{2}\right)$ and decrease in $\mathrm{CO}_{2}$ and is most likely associated with the change in sampled air mass from that measured near the South Island, and therefore containing terrestrial and anthropogenic influence, to that from the open ocean. The westerly winds prevailed throughout most of the remaining voyage until 27 April, at $48^{\circ} \mathrm{S}$, when it changed back to easterly. However, from the meteorological data, there is no clear explanation for why such high $\delta\left(\mathrm{O}_{2} / \mathrm{N}_{2}\right)$ was observed between $55^{\circ} \mathrm{S}$ and $47^{\circ} \mathrm{S}$. Therefore, to help find the origin of this signal, we used a trajectory model (HySplit4) (Draxler and Hess, 1998).

We used 72-h back-calculated trajectories at approximately 6-hourly intervals from the ship's position throughout the voyage. We chose to show only those trajectories covering the period just before the high $\delta\left(\mathrm{O}_{2} / \mathrm{N}_{2}\right)$ excursion to just afterwards, that is, starting from $0900 \mathrm{~h}$ on 25 April and ending at $1900 \mathrm{~h}$ on 28 April (see Fig. 9). From 25 April to early on 26 April, the trajectories show air masses being transported across the open ocean south of New Zealand, as was the case for the entire duration of the southbound leg. However, as Tangaroa proceeded further north, to $53^{\circ} \mathrm{S}$, the trajectories indicate that the sampled air masses were following a path closer to the coast, coinciding with the observations of high $\delta\left(\mathrm{O}_{2} / \mathrm{N}_{2}\right)$. North of $50^{\circ} \mathrm{S}$, the trajectory

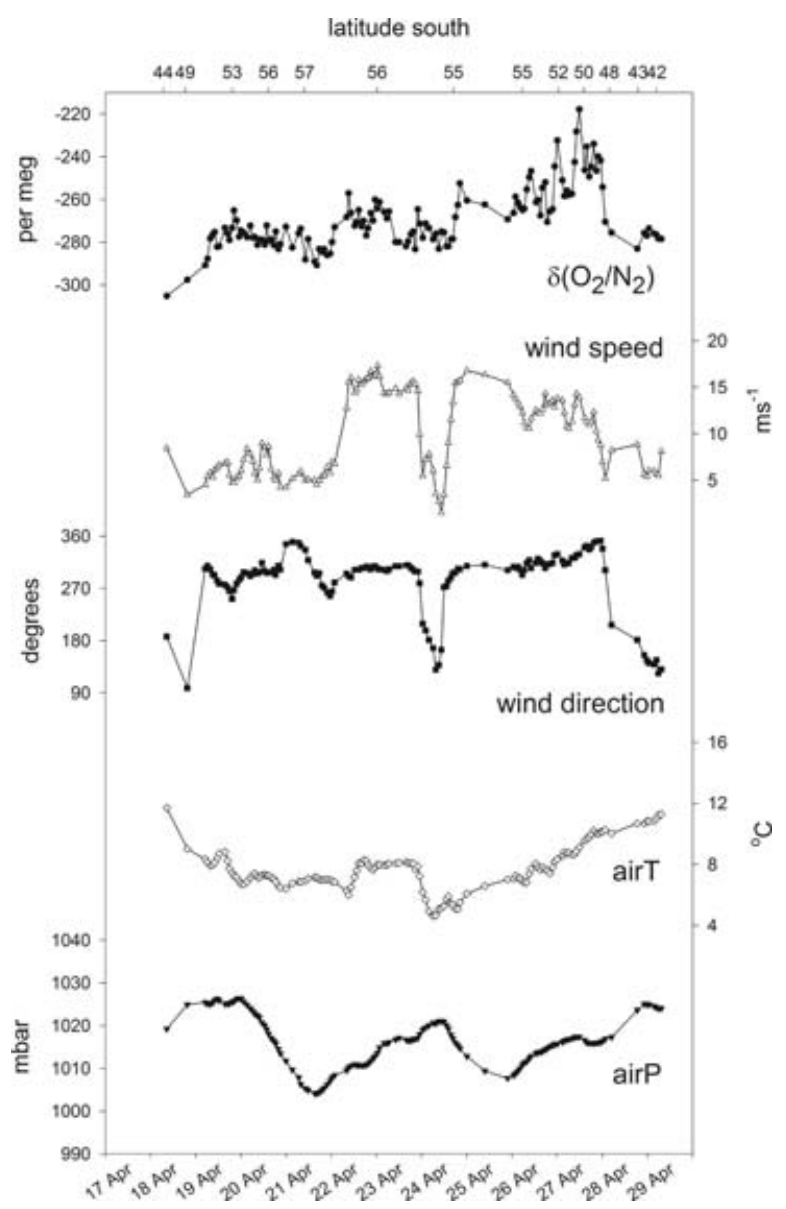

Fig. 8. April 2004: hourly mean $\left(\mathrm{O}_{2} / \mathrm{N}_{2}\right)$ and meteorological data (collected onboard Tangaroa) plotted versus time with the approximate latitude indicated on the upper $x$-axis.

path changed again transporting air south from the east coast of the South Island, consistent with the change in wind direction seen in the shipboard meteorology, and high $\delta\left(\mathrm{O}_{2} / \mathrm{N}_{2}\right)$ was still observed. Late on 27 April, the trajectory path changed further, bringing air from off the South Island and coincided with the fall in $\delta\left(\mathrm{O}_{2} / \mathrm{N}_{2}\right)$. Although not shown here, the heights of the trajectories throughout this time were below $400 \mathrm{~m}$, that is, within the marine boundary layer, and hence those trajectories over the ocean should be largely representative of the local air-sea gas exchanges.

We propose that the high $\delta\left(\mathrm{O}_{2} / \mathrm{N}_{2}\right)$ signal is caused by biologically driven $\mathrm{O}_{2}$ outgassing in the regions east of the South Island, over the Chatham Rise, as well as south of the South Island, over the Campbell Plateau (see Fig. 4). SeaWiFs satellite data for April 2004 show a belt of high chlorophyll $a$ concentration water, up to $0.9 \mathrm{mg} \mathrm{m}^{-3}$, extending to the east and to the south of the South Island over both these regions. The Chatham Rise and the Campbell Plateau have been shown to be a highly productive owing to the mixing of the Sub-Antarctic current with the subtropical current, which occurs south of the South Island, 


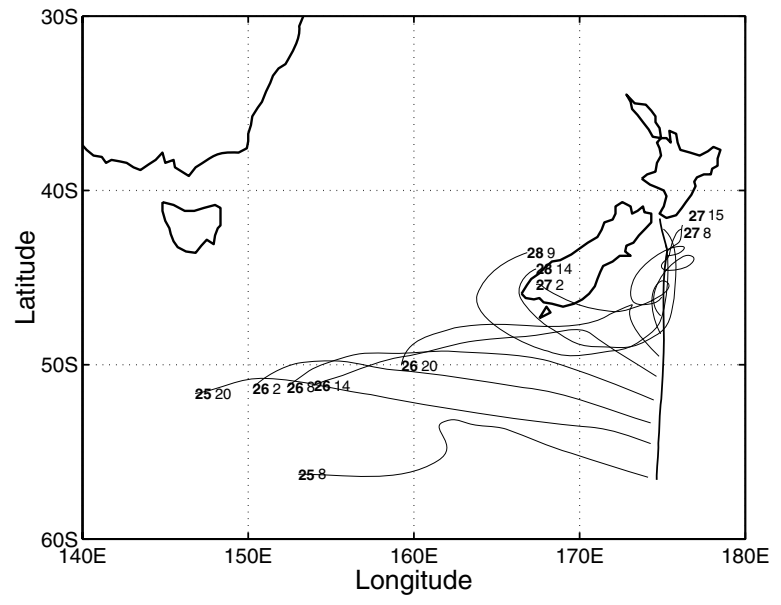

Fig. 9. Back trajectories calculated at 6-hourly intervals starting from the ship's position and plotted back over $72 \mathrm{~h}$ using the HySplit4 model. Trajectories are shown for the period: 090025 April to 190028 April with the date (bold font) and hour (normal font) corresponding with arrival at the ship.

along the southeastern coast and across the Chatham Rise (Boyd et al., 1999; Chiswell, 2001).

To test this supposition, we estimate the $\mathrm{O}_{2}$ flux, and subsequently the change in $\mathrm{O}_{2}$ concentration in the surface layer, that would be needed to produce the observed atmospheric $\mathrm{O}_{2}$ signal. This calculation computes the flux into a moving air mass allowing for the degree of vertical mixing that would occur over the time of the computation. The flux into a well-mixed moving column of air is defined in eq. (10) and is based on the formulation of Jacob (1999):

$F=\frac{\Delta C h}{t[1-\exp (-L / u t)]}$,

where $F$ is the ocean-atmosphere flux of the species, $\Delta C$ is the change in its atmospheric concentration, $L$ is the wind fetch, $u$ is the wind speed and $h$ is the vertical mixing height. For these calculations, we used a wind fetch of $1000 \mathrm{~km}$, a vertical mixing height of $400 \mathrm{~m}$ and the mean observed wind speed of $12 \mathrm{~ms}^{-1}$ as measured by Tangaroa for 26 to 27 April. The factor, $t$, is the time taken for $C$ to reach $1 / e$ of its initial value due to atmospheric mixing; here we used $t=12 \mathrm{~h}$. We found that for the change in atmospheric $\mathrm{O}_{2}$ between $53^{\circ} \mathrm{S}$ and $50^{\circ} \mathrm{S}$, that is, $\Delta C=48$ per meg, a flux of $148 \mathrm{~mol} \mathrm{~m}^{-2} \mathrm{yr}^{-1}$ is required, or in terms of a change in dissolved $\mathrm{O}_{2}$ concentration, $47 \mu \mathrm{molL}^{-1}$ (using the formulation of gas exchange velocity of Wanninkhof, 1992). Although no measurements of dissolved $\mathrm{O}_{2}$ concentration are available for the subtropical convergence zone around New Zealand at this time, our calculated change in $\mathrm{O}_{2}$ is compatible with measurements of $\mathrm{O}_{2}$ production in phytoplankton blooms. For example, a study in the Ross Sea by Bender et al. (2000), found $\mathrm{O}_{2}$ in the surface layer to change at a rate of up to $17 \mu \mathrm{molL}^{-1}$ per day as a result of gross primary production. In addition, measurements made in the Chatham Rise region in
April 2004, just prior to our voyage, showed substantial $\mathrm{pCO}_{2}$ undersaturation (K. Currie, personal communication, 2007) and further supports the supposition that the high $\delta\left(\mathrm{O}_{2} / \mathrm{N}_{2}\right)$ signal was the result of biological production.

The $\mathrm{O}_{2}: \mathrm{CO}_{2}\left[\mathrm{~mol} \mathrm{~mol}^{-1}\right]$ ratio can be used to aid in the determination of the origins of observed atmospheric $\mathrm{O}_{2}$ and $\mathrm{CO}_{2}$ signals. For instance, a ratio of around -1.1 is indicative of terrestrial exchanges (Severinghaus, 1995) and more negative ratios are indicative of fossil fuel burning [up to about -2.0 for combustion of $\mathrm{CH}_{4}$ and about -1.4 for the global average of fossil fuels (Keeling, 1988a; Marland et al., 2000; )]. We calculated $\mathrm{O}_{2}: \mathrm{CO}_{2}$ for the voyage and found that this ratio changed significantly for different regions. At the start of the southbound leg, when low $\delta\left(\mathrm{O}_{2} / \mathrm{N}_{2}\right)$ and high $\mathrm{CO}_{2}$ were observed, $\mathrm{O}_{2}: \mathrm{CO}_{2}=$ $-0.9\left(R^{2}=0.7\right)$. Although this ratio is less negative than the -1.1 normally quoted for terrestrial exchanges (Severinghaus, 1995) it is within the range of recent measurements of this ratio for terrestrial ecosystems, from -1.0 (Stephens et al., 2007) and -0.7 (Seibt et al. 2004). Furthermore, back trajectories calculated for this time (not shown) indicate that this air was in contact with the middle of the South Island. South of $49^{\circ} \mathrm{S}, \mathrm{O}_{2}: \mathrm{CO}_{2}=$ $5.3\left(R^{2}=0.2\right)$, the positive ratio indicating that heat flux was probably an important driver of ocean-atmosphere exchange, as it drives flux in the same direction for both gases. However, on the northbound leg, and during the period of high $\delta\left(\mathrm{O}_{2} / \mathrm{N}_{2}\right)$, there was no significant correlation of $\mathrm{O}_{2}$ with $\mathrm{CO}_{2}$. We propose that this result is due to biological production, which was driving $\mathrm{O}_{2}$ outgassing and $\mathrm{CO}_{2}$ uptake, in combination with heat driven $\mathrm{O}_{2}$ and $\mathrm{CO}_{2}$ exchange, which was driving $\mathrm{O}_{2}$ and $\mathrm{CO}_{2}$ in the same direction.

\subsection{Comparisons with observations from the SIO flask-sampling network and Baring Head Station}

Spatial gradients in APO can be used to derive spatial patterns in air-sea $\mathrm{O}_{2}$ and $\mathrm{CO}_{2}$ fluxes (e.g. Stephens et al., 1998; Battle et al., 2006). However, there is considerable uncertainty in the APO gradient from the mid- to high-southern latitudes (Stephens et al., 1998) owing to the paucity of data available. Currently there are only seven flask-sampling stations, and one continuous station measuring atmospheric $\mathrm{O}_{2}$ in the Southern Hemisphere. The ship-based observations of Battle et al. (2006) extend only to $30^{\circ} \mathrm{S}$ and prior to this study there had been only one set of measurements in the Southern Ocean, across the Drake Passage (Stephens et al., 2003).

To examine how our observations compared with APO gradients observed from the existing station measurements, we plotted APO from our shipboard measurements and APO from monthly averages of flask samples in the SIO network (R. Keeling, personal communication, 2004) and monthly averages of continuous measurements at the NIWA atmospheric station (G. Brailsford, personal communication, 2004), Baring Head (BHD) near Wellington, New Zealand (Fig. 10). One striking 

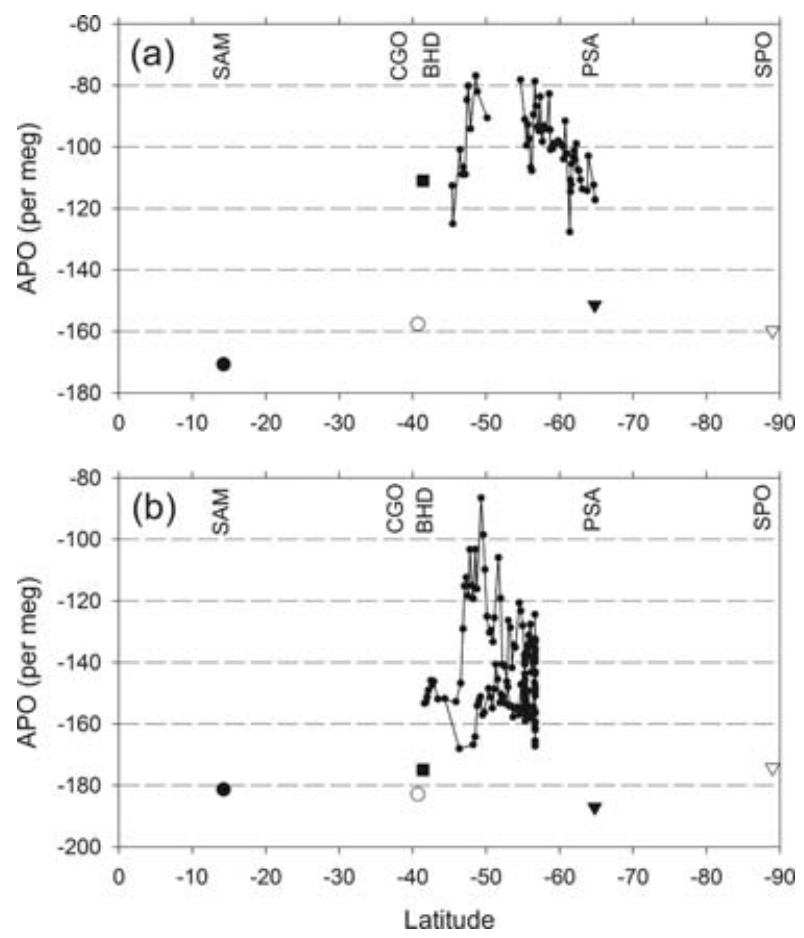

Fig. 10. APO from the shipboard observations (black dots) shown as hourly averages compared with monthly mean APO, centred on the 15 th of the month, from stations in the SIO flask-sampling network, namely, Samoa (SAM, $\left.14^{\circ} \mathrm{S}, 171^{\circ} \mathrm{W}\right)$, Cape Grim (CGO, $41^{\circ} \mathrm{S}$, $145^{\circ} \mathrm{E}$ ), Palmer Station (PSA, $64^{\circ} \mathrm{S}, 64^{\circ} \mathrm{W}$ ) and South Pole (SPO, $\left.89^{\circ} \mathrm{S}, 25^{\circ} \mathrm{W}\right)$. Also shown is the monthly mean concentration at Baring Head (BHD, $41^{\circ} \mathrm{S}, 175^{\circ} \mathrm{E}$ ) from continuous measurements (black square) (a) February 2003 voyage and (b) April 2004 voyage.

feature shown in Fig. 10a, is the much higher APO at BHD and from our shipboard measurements compared with the SIO stations in February 2003. Although we cannot exclude the possibility that part of this difference may be due to a calibration offset, later inter-comparisons between SIO and NIWA (in December 2004) suggest that any potential offset is less than 10 per meg and therefore would only explain about one third of the difference. The remainder may be in fact due to differences in atmospheric transport; while BHD and CGO lie at similar latitudes, at BHD 'clean-air' is received from the south to southwest, so is more representative of the western Pacific sector of the Southern Ocean, whereas at CGO 'clean-air' is received from the west and is more representative of the Indian Ocean region. This difference has been suggested to contribute considerably to differences in concentration observed between the two stations (Manning, 2001). In addition, it should be noted that BHD measures $\mathrm{O}_{2}$ continuously whereas the monthly averages from SIO network stations are taken from biweekly flask samples and therefore may be susceptible to synoptic variations and not representative of the month as a whole.

Not surprisingly, APO data from the shipboard measurements are closer to that of BHD, since both were sampling air from largely the same region. However, what the measurements made along the ship transect show, that is for both the February 2003 and April 2004 voyages, is an APO maximum centred on $50^{\circ} \mathrm{S}$ and a decreasing APO trend to the south of this maximum. Although this maximum was not observed on the southbound leg of the April 2004 voyage, owing to the meteorological conditions, this feature is likely to be a result of biologically driven $\mathrm{O}_{2}$ fluxes in the biologically productive regions of the Chatham Rise and Campbell Plateau (see Fig. 4).

\section{Summary}

We have presented a method for achieving high precision measurements of atmospheric $\mathrm{O}_{2}$ using a commercially available fuel cell-based instrument, Oxzilla FC-II. With rigorous gas handling, we are able to achieve precision for $\mathrm{O}_{2}$ of 7 per meg, and for $\mathrm{CO}_{2}$ of $0.1 \mathrm{ppm}$ (using a LICOR 6252), over a 6-min averaging interval. This is sufficient to determine the small changes in background $\mathrm{O}_{2}$ and $\mathrm{CO}_{2}$ concentrations expected over the ocean. We deployed this system on the research ship, Tangaroa, on two voyages in the western Pacific sector of the Southern Ocean. These data show significant short-term variability, in the order of \pm 10 per meg in February 2003, and \pm 5 per meg in April 2004 over 6-h intervals. In addition, our continuous ship-based measurements showed considerable spatial variability, which is not apparent in the SIO network observations owing to the paucity of stations. Most notably, we observed an APO maximum centred about $50^{\circ} \mathrm{S}$, which on the northbound leg of the April voyage appears to be the result of biologically driven outgassing in the regions of the Chatham Rise and the Campbell Plateau, and on both voyages we found a decreasing APO trend southwards from $50^{\circ} \mathrm{S}$ that was also not captured by the station network observations.

\section{Acknowledgments}

We gratefully acknowledge the help and advice of John McGregor and Gordon Brailsford and thank the crew of Tangaroa for their outstanding support and co-operation. We thank Ralph Keeling for allowing us to use flask data from the SIO network and Gordon Brailsford for the use of Baring Head data. We are also very grateful for the financial support of the New Zealand National Institute for Water and Atmospheric Research, Victoria University of Wellington, and funding from the New Zealand Foundation of Science, Research and Technology.

\section{References}

Battle, M., Mikaloff Fletcher, S., Bender, M. L., Keeling, R. F., Manning, A. C. and co-authors. 2006. Atmospheric potential oxygen: new observations and their implications for some atmospheric and oceanic models. Global Biogeochem. Cycles 20, GB1010, doi:10.1029/2005GB002534.

Bender, M. L., Tans, P. P., Ellis, J. T., Orchardo, J. and Habfast, K. 1994. A high precision isotope mass spectrometry method for 
measuring the $\mathrm{O}_{2} / \mathrm{N}_{2}$ ratio of air. Geochim. Cosmochim. Acta 38, 4751-4758.

Bender, M. L., Ellis, T., Tans, P. P., Francey, R. and Lowe, D. 1996. Variability in the $\mathrm{O}_{2} / \mathrm{N}_{2}$ ratio of southern hemisphere air, 1991-1994: implications for the carbon cycle. Global Biogeochem. Cycles 10, 9 21.

Bender, M. L., Dickson, M. L. and Orchardo, J. 2000. Net and gross production in the Ross Sea as determined by incubation experiments and dissolved $\mathrm{O}_{2}$ studies. Deep-Sea Res. II 47, 3141-3158.

Boyd, P. W., LaRoche, J., Gall, M., Frew, R. and McKay, R. 1999. Role of iron, light and silicate in controlling agal biomass in sub-antarctic waters SE of New Zealand. J. Geophys. Res. 104, 13391-13404.

Broecker, W. S. and Peng, T. H. 1974. Gas exchange rates between air and sea. Tellus 26, 21-35.

Burton, J. 1967. Standard gas mixtures and their use in iron and steel works. Rev Metall. (Paris) 64, 73-80.

Chapman, S. and Cowling, T. G. 1970. The Mathematical Theory of Non-Uniform Gases. Cambridge University Library, Cambridge, pp. 423.

Chiswell, S. M. 2001. Eddy energetics in the Subtropical Front over the Chatham Rise, New Zealand. New Zealand J. Mar. Freshwater Res. 35, 1-15.

Draxler, R. R. and Hess, G. D. 1998. An overview of the Hysplit4 modelling system for trajectories, dispersion, and deposition. Aust. Meteorol. Mag. 47, 295-308.

Dushman, S. 1962. Scientific Foundations of Vacuum Technique. John Wiley, New York, 806 pp.

Gruber, N., Gloor, M., Fan, S. and Sarmiento J. L. 2001. Air-sea flux of oxygen estimated from bulk data: implications for marine and atmospheric oxygen cycles. Global Biogeochem. Cycles 15, 783-803.

Jacob, D. 1999. An Introduction to Atmospheric Chemistry. Princeton University Press, Princeton, 266 pp.

Keeling, R. F. 1988a. Development of an Interferometric Oxygen Analyzer for Precise Measurement of the Atmospheric $\mathrm{O}_{2}$ Mole Fraction. $\mathrm{PhD}$ Thesis, Harvard University, 178 pp.

Keeling, R. F. 1988b. Measuring correlations between atmospheric oxygen and carbon dioxide mole fractions: a preliminary study in urban air. J. Atmos. Chem. 7, 153-176.

Keeling, R. F. and Shertz, S. R. 1992. Seasonal and inter-annual variations in atmospheric oxygen and implications for the global carbon cycle. Nature 358, 723-727.

Keeling, R. F., Piper, S. C. and Heimann, M. 1996. Global and hemispheric $\mathrm{CO}_{2}$ sinks deduced from changes in atmospheric $\mathrm{O}_{2}$ concentration. Nature 381, 218-221.

Keeling, R. F., Manning, A., McEvoy, E. M. and Shertz, S. R. 1998. Methods for measuring changes in atmospheric $\mathrm{O}_{2}$ concentration and their application in southern hemisphere air. J. Geophys. Res. 103, 3381-3307.

Keeling, R. F. and Garcia, H. E. 2002. The change in oceanic $\mathrm{O}_{2}$ inventory associated with recent global warming. Proc. Natl. Acad. Sci. 99, 7848-7853.

Keeling, R. F., Manning, A. C., Paplawsky, W. J. and Cox, A. C. 2007. On the long-term stability of reference gases for atmospheric $\mathrm{O}_{2} / \mathrm{N}_{2}$ and $\mathrm{CO}_{2}$ measurements. Tellus 59B, 3-14.

Langenfelds, R. L., Van Der Schoot, M. V., Francey, R. J., Steele, L. P., Schmidt, M. and co-authors. 2005. Modification of air standard composition by diffusive and surface processes. J. Geophys. Res. 110, D13307, doi:10.1029/2004JD005482.
Machta, L. and Hughes, E. 1970. Atmospheric oxygen in 1967 to 1970. Science 168, 1582-1584.

Manning, A., Keeling, R. F. and Severinghaus, J. P. 1999. Precise atmospheric oxygen measurements with a paramagnetic oxygen analyzer. Global Biogeochem. Cycles 13, 1107-1115.

Manning, A. C. 2001. Temporal Variability of Atmospheric Oxygen from both Continuous Measurements and a Flask-Sampling Network: Tools for Studying the Global Carbon Cycle. PhD Thesis. Scripps Institution of Oceanography, University of California, $202 \mathrm{pp}$.

Manning, A. C. and Keeling, R. F. 2006. Global oceanic and land biotic carbon sinks from the Scripps atmospheric oxygen flask sampling network. Tellus 58B, 95-116.

Marland, G., Boden, T. A. and Andres, R. J. 2000. Global, regional and national $\mathrm{CO}_{2}$ emissions. In: Trends: A Compendium of Data on Global Change, Carbon Dioxide Information Analysis Centre, Oak Ridge National Laboratory, U.S. Department of Energy, Oak Ridge.

Rintoul, S. R., Hughes, C. W. and Ollsers, D. 2001. The Antarctic circumpolar current system. In: Ocean Circulation and Climate (eds G. Siedler, J. Church and J. Gould). Academic Press, London, 431-454.

Sarmiento, J., Murnane, R. and Le Quéré, C. 1995. Air-sea $\mathrm{CO}_{2}$ transfer and the carbon budget of the North Atlantic. Philos. Trans. Roy. Soc., London Ser. B 348, 211-219.

Seibt, U., Brand, W. A., Heimann, M. and Lloyd, J. 2004. Observations of $\mathrm{O}_{2}: \mathrm{CO}_{2}$ exchange ratios during ecosystem gas exchange. Global Biogeochem. Cycles 18, GB4024, doi:10.1029/2004GB002242.

Severinghaus, J. P. 1995. Studies of the Terrestrial $\mathrm{O}_{2}$ and Carbon $\mathrm{Cy}$ cles in Sand Dune Gases and in Biosphere 2. PhD Thesis. Columbia University, $148 \mathrm{pp}$.

Severinghaus, J. P., Bender, M. L., Keeling, R. F. and Broecker, W. S. 1996. Fractionation of soil gases by diffusion of water vapor, gravitational settling and thermal diffusion. Geochim. Cosmochim. Acta $\mathbf{6 0}$, 1005-1018.

Stephens, B. B., Keeling, R. F., Heimann, M., Six, K. D., Murnane, R. and co-authors. 1998. Testing global ocean carbon cycle models using measurements of atmospheric $\mathrm{O}_{2}$ and $\mathrm{CO}_{2}$ concentration. Global Biogeochem. Cycles 12, 213-230

Stephens, B. B. 1999. Field-based Atmospheric Oxygen Measurements and the Ocean Carbon Cycle. $\mathrm{PhD}$ Thesis. Scripps Institution of Oceanography, University of California, $221 \mathrm{pp}$.

Stephens, B. B., Keeling, R. F. and Paplawsky, W. J. 2003. Shipboard measurements of atmospheric oxygen using a vacuum-ultraviolet absorption technique. Tellus 55B, 857-878.

Stephens, B. B., Bawkin, P., Tans, P. P., Teclaw, R. and Baumann, D. 2007. Application of a differential fuel-cell analyzer for measuring atmospheric oxygen variations. J. Atmos Oc. Tech. 24, 82-94.

Tohjima, Y. 2000. Method for measuring changes in the atmospheric $\mathrm{O}_{2} / \mathrm{N}_{2}$ ratio by a gas chromatograph equipped with a thermal conductivity detector. J. Geophys. Res. 105, 14575-14584.

Tohjima, Y., Mukai, H., Machida, T., Nojiri, Y. and Gloor, M. 2005. First measurements of the latitudinal atmospheric $\mathrm{O}_{2}$ and $\mathrm{CO}_{2}$ distributions across the western Pacific. Geophys. Res. Lett. 32, L17805.

Volk, T. and Hoffert, M. I. 1985. Ocean carbon pumps: Analysis of relative strengths and efficiencies in ocean-driven atmospheric $\mathrm{CO}_{2}$ changes. In: The Carbon Cycle and Atmospheric $\mathrm{CO}_{2}$ : Natural Variations Archean to Present (eds E. T. Sundquist and W. S. Broecker), American Geophysical Union, Washington DC, 99-110.

Wanninkhof, R. 1992. Relationship between wind speed and gas exchange over the ocean. J. Geophys. Res. 97, 7373-7382. 